(C) Дж. Блундо

\title{
КОРРУПЦИЯ И ГОСУДАРСТВО В САХЕЛЕ
}

Ключевые слова: коррупция, государство, бюрократия, клиентелизм, good governance, международные доноры, общественные движения, Сахель

\begin{abstract}
Начиная с 2000 гг. новые инструменты оценки борьбы с коррупцией создают нелестный образ государств Сахеля. Согласно наиболее известному из них - Списку стран по восприятию коррупции (Corruption Perception Index, CPI), составляемому международной неправительственной организацией Transparency International, в 2016 г. практически все страны региона попали в группу государств с эндемической коррупцией. Однако восприятие коррупции внутри группы варьирует: Сенегал и Буркина Фасо считаются менее коррумпированными, чем Мали и Нигер, которые, в свою очередь, выглядят лучше Мавритании и особенно Чада, входящего в список 20 наиболее коррумпированных стран мира - вместе с Бурунди, Гаити, Центральноафриканской Республикой и Демократической Республикой Конго. Однако эти чисто количественные и вырванные из контекста измерения проливают мало света на социальное и культурное обрамление повседневной коррупции. Настоящая статья опирается на качественные эмпирические полевые исследования, ведущиеся автором в Нигере, Сенегале и Мавритании.
\end{abstract}

\section{Коррупция и государствостроительство}

Колониальное наследие. Теме коррупции ${ }^{1}$ в Африке посвящено немало работ. Однако редкими остаются эмпирические исследования, поскольку данный феномен относится к числу трудно наблюдаемых и измеряемых. В странах Сахеля он изучен еще хуже, чем в других частях Африканского континента: согласно единственному имеющемуся на сегодня историографическому обзору (Blundo 2006a), более половины работ, опубликованных между 1960 и 2005 гг, касаются англоязычной части региона. Отметим, кроме того, что если изучение коррупции в Нигере и Сенегале активно идет с конца 1990-х гг., то литература по Мали, Буркина-Фасо, Чаду и особенно Мавритании носит фрагментарный, узко специальный характер и не позволяет осуществить полноценный сравнительный анализ. Наконец, до сих пор нет обобщающего исследования по всему региону.

Джорджо Блундо | https://orcid.org/ 0000-0003-2432-3114 | Центр Норберта Элиаса | 2 rue de la Charité, 13002 Marseille, France |giorgio.blundo@ehess.fr

Статья представляет собой перевод расширенной франкоязычной версии опубликованного английского текста: Blundo, Giorgio. 2021. Corruption and the State in the Sahel. In Leonardo A. Villalón, ed. The Oxford Handbook of the African Sahel. Oxford: Oxford University Press. Автор благодарит издателей книги за разрешение публикации статьи на русском языке.

Для цитирования: Дж. Блундо. Коррупция и государство в Сахеле. // Антропологии/Anthropologies. 2021. № 1. C. 97-120. https://doi.org/10.33876/2782-3423/2021-1/97-120. 
Начиная с 2000 гг. новые инструменты оценки борьбы с коррупцией создают нелестный образ государств Сахеля. Согласно наиболее известному из них - Списку стран по восприятию коррупции (Corruption Perception Index, CPI), составляемому международной неправительственной организацией Transparency International ${ }^{2}$, в 2016 г. все страны региона, за исключением (и то едва) Сенегала попали в группу государств с эндемической коррупцией (показатель ниже 43). Однако восприятие коррупции внутри группы варьирует: Сенегал и Буркина Фасо считаются менее коррумпированными, чем Мали и Нигер, которые, в свою очередь, выглядят лучше Мавритании и особенно Чада, входящего в список 20 наиболее коррумпированных стран мира - вместе с Бурунди, Гаити, Центральноафриканской Республикой и Демократической Республикой Конго. Рассчитанные на основании опросов общественного мнения или массовых количественных исследований, эти индексы лишь сравнивают в планетарном масштабе представления, полностью вырванные из контекста. За кажущимся наукообразием этих цифр кроются инструменты давления, поскольку плохой рейтинг несет в себе риск сокращения международной помощи. (Более подробный критический анализ см.: Blundo, Olivier de Sardan 2000, de Maria 2008).

Точно датировать возникновение коррупционных практик в регионе не представляется возможным. Можно сразу отбросить две противоположных, но равно внеисторических и идеологизированных точки зрения. Согласно первой из них, современная коррупция в Сахеле представляет собой пережитки традиционных социальных практик и логик в современном политическом контексте. Согласно второй - она пришла в Африку вместе с колониальным государством. Наиболее радикальный взгляд состоит в том, что колонизация извратила фундаментально честные традиционные общества и политии. Мы склонны согласиться с теми авторами (Bayart 1989, Olivier de Sardan 1999), которые полагают, что современная коррупция в Сахеле является результатом сложного процесса взаимопроникновения колониального, а затем независимого государства и местных политических культур.

Вплоть до начала французской колонизации на большей части территории Сахеля существовали в лучшем случае формы протогосударственной политической организации, контролировавшей местные общины с помощью методов, более похожих на рэкет, чем на взимание налогов (Ould Cheikh 2003). В контексте родовых отношений господства и подчинения "современные” проявления коррупции (предполагающие разделение на частную и публичную сферы) были невозможны. Тем не менее, обычное право порицало и наказывало такое поведение властителей, которое шло вразрез с коллективными интересами в угоду личной выгоде (Jacob 2001). Злоупотребление властью и хищнические наклонности “языческих" вождей служили, кроме того, оправданием священных войн (jihad), сотрясавших регион на всем протяжении XIX в. (Smith 1964).

Одним из наследий колониальной системы стал благоприятный для коррупционных практик политический и институциональный климат. Несмотря на порой значительные различия в механизмах управления от страны к стране ${ }^{3}$, колониальная бюрократия не имела ничего общего ни с доколониальными, ни с современными европейскими формами власти (Olivier de Sardan 2004). Она была сосредоточена в основном в городах, остальная же территория управлялась рыхлой бюрократической структурой, немногочисленные агенты которой делегировали полномочия разнообразным помощникам и посредникам из числа местного населения (вождям кантонов, переводчикам, кадиям, лесникам и т.п.). Благодаря сосредоточению в их руках отправления обычного права, сбора налогов и рекрутирования на различные работы, эти местные посредники смогли заметно обогатиться, монетизируя свою власть 
и пользуясь известной безнаказанностью. Так, в Сенегале “абсолютное большинство кадиев было озабочено только тем, как обогатиться за счет просителей” (Gueye 1997: 155), в то время как в Чаде верные французской военной администрации марабуты не гнушались мародерством, набегами и даже работорговлей (Arditi 2000). В Нигере, как и повсюду, подношения вождям утратили ритуальное значение и превратились в настоящую дань, взимавшуюся по самым различным поводам: за сокращение числа голов скота, подлежащего реквизиции, за освобождение детей от учебы в школе “белых” или при обращении к традиционному суду (Olivier de Sardan 1984: 207-224). В Западной и Экваториальной французской Африке колониальная администрация не была свободна от коррупции и беззаконий, при этом “наказания белых чиновников в колониях были редкостью” (Brunschwig 1983: 26). Помимо административной культуры, основанной на безнаказанности, деспотизме, произволе и использовании посредников, колониальное государство утвердило в обществе образ системы власти, нацеленной на обслуживание частных интересов колонизаторов и их клиентелы в ущерб общественному интересу; большинство населения имело статус аборигенов и было лишено самых элементарных прав. Чередуя санкции и привилегии для “заслуживающих”, т.е. верных колониальной администрации, подданных - привилегии, которых они могли лишиться в любой момент, - колониальная администрация создала подобие придворного общества со своими изгоями, фаворитами и куртизанами (Touquet 2010).

Однопартийные системы и военные режсимы. Однопартийные системы, взявшие на себя задачу построения национальных государств вскоре после обретения независимости, укрепились благодаря различным рентам: геополитической ренте в контексте холодной войны и системы “Франсафрик” (Verschave 1998, Verschave 2000); сельскохозяйственной (арахис в Сенегале, хлопок в Буркина Фасо и Мали); горнорудной (железо в Мавритании, уран в Нигере, фосфаты в Сенегале); ренте помощи в развитии (Magrin 2010). Они стали питательной средой мощных политических образований, в которых “традиционные” патроны (марабуты исламских братств в Сенегале, административное вождество в Нигере, крупные торговцы в Мали и Чаде и т.п.) выступают в роли посредников между партийной элитой и сельским населением. С первых двух десятилетий после обретения независимости коррупция стала способом управления людьми, неотрывным от властвования над ними. Опираясь на перераспределение клиентелистского типа, тогдашние лидеры сумели обеспечить выживание своих режимов и придать им некоторую легитимность и стабильность. Крупные государственные компании развития стали объектом систематического расхищения бюрократическими клиентелами и коммерсантами, объединившимися в высших органах “партий-государств”: сенегальское Национальное бюро кооперации и содействия развитию (ONCAD), созданное для координации арахисовой экономики, оставило после своего роспуска в 1980 г. долг в 90 млрд африканских франков (Franc CFA); 20-миллиардный годовой бюджет организации Хлопок-Чад регулярно использовался не по назначению по приказу президента Х. Хабре (Arditi 2000).

До тех пор, пока рента - как внешняя, так и внутренняя - сохранялась стабильной, уровень коррупции ограничивался и контролировался политическими лидерами. Так, Мавритания, пораженная сегодня гангреной коррупции, была относительно свободна от нее в первые полтора десятилетия своего существования: режим первого президента Моктара ульд Дадда (1960-1978) известен тем, что он заложил основы современного государства, опираясь на честную и пуританскую элиту (Blundo 2011b).

Поразившие регион на рубеже 1970-х гг. засухи стали первым фактором усиления коррупции: интенсифицировавшийся исход сельского населения увеличил нагрузку на государствен- 
ные службы, оказавшиеся к этому неготовыми. Деньги, полученные в виде экстренной помощи, были в основном растрачены нецелевым образом.

На протяжении десятилетия 1965-1975 гг. все гражданские политические режимы в Сахеле (за исключением Сенегала) были свергнуты военными, в большинстве случаев под лозунгом оздоровления общественной жизни. Однако, не считая Буркина-Фасо, где революционное правительство Т. Санкара продемонстрировало свою неподкупность в ходе показательных кампаний против бюрократической бесхозяйственности (Sarassoro 1990), и Нигера в годы правления Сейни Кунче, беспощадно и последовательно боровшегося с коррупцией (Атижо 1986), ни один военный режим сам не был свободен от этого феномена. Напротив, приход к власти военных привел к банализации коррупции: в Мавритании переворот, свергнувший Ульд Дадда в 1978 г., был совершен кланами, оттесненными от власти гражданским режимом и стремившимися занять ключевые посты в государстве, чтобы в свою очередь обогатиться (Blundo 2011b).

Эpa “good governance”. На всем протяжении 1990-х гг. феномен коррупции становится все более обсуждаемым, благодаря процессу политической либерализации и появлению относительно свободной прессы ${ }^{4}$. В Нигере и Сенегале - странах, для которых у нас есть сравнительно новые данные, статьи, разоблачающие коррупцию, также получили самое широкое распространение именно в этот период 5

Параллельно общественная жизнь стала деградировать в самых разных сферах. После эйфории национальных конференцийб “демократизация” показала свое истинное лицо. Приватизация, необузданный экономический либерализм, продолжающиеся сокращения государственных служащих вслед за программами структурной перестройки предшествующего десятилетия, разгосударствление. В этом контексте всеобщей деградации государственных служб начался быстрый подъем мелкой административной коррупции, которому способствовало также обыденное понимание политической либерализации как более равноправного доступа к хищническому обогащению (Fay 1995). C восстановлением многопартийности коррупция на выборах и электоральный клиентелизм расцвели пышным цветом, как показывает масштабное исследование в Нигере, выводы которого можно распространить на весь Сахель (Olivier de Sardan 2015).

Принципы good governance, направленные на расширение участия населения в решении местных проблем, а также реформы в русле децентрализации на практике привели к поспешной передаче компетенций на муниципальный уровень - в руки коммун, безусловно, нуждающихся в людских и финансовых ресурсах, но представляющих собой новые пространства хищнического обогащения местных элит. В нескольких странах региона, начиная с Сенегала, где еще в 1972 г. появились местные органы управления (Blundo 2001b), вплоть до Нигерии с ее совсем недавно созданными коммунами (Olivier de Sardan, Tidjani Alou 2009), децентрализация является также примером делокализации финансовых злоупотреблений и перераспределения средств внутри клиентелистских сетей.

Таким образом, любая политическая модель (будь она авторитарная или плюралистская, военная или гражданская, централизованная или децентрализованная), равно благоприятна для расцвета коррупции. Тем не менее, именно проблема плохого управления проходит красной нитью через все политические пертурбации в Сахеле: оно направляет народную ненависть против незаконного обогащения свергнутых властителей и служит оправданием для нового политического класса в его стремлении с помощью избирательных антикоррупционных 
кампаний окончательно устранить политических противников. Таким образом, как “законно избранные", так и переходные правительства создают самые необузданные формы хищничества: несмотря на неоднократные обещания перемен, приведших его к власти в марте 2000 г., сенегальский президент Абдулай Вад постепенно установил режим личной власти, основанный на клиентелистском перераспределении общественных ресурсов и на невиданном прежде уровне коррупции.

\section{Практики и механизмы повседневной коррупции}

В Сахеле, как и повсюду на африканском континенте, “большая коррупция” давно глобализована, коренится в своих излюбленных сферах (рынок вооружений, эксплуатация горнорудных ресурсов, строительство и общественные работы, международная помощь, банковский сектор, импорт-экспорт и т.п.), оперирует крупными суммами денег (особенно в сравнении с низким уровнем транзакций в национальных экономиках) и обогащает в основном элиты. Даже если она поражает своим размахом и своей необходимостью для выживания региональных политических элит, по своей природе и механизмам она принципиально не отличается от коррупции в верхних эшелонах власти в других частях света.

Специфику Сахеля составляет именно мелкая повседневная коррупция. Она проявляется преимущественно при оказании базовых государственных услуг, а также в ежедневном взаимодействии населения с бюрократами-чиновниками, и имеет системный характер, будучи скорее нормой, чем исключением. Коррупция пронизывает все сферы административной деятельности и общественной жизни, она глубоко укоренилась в системе общей дисфункции органов управления и неоднозначно воспринимается гражданами, которые также активно разоблачают ее, как и практикуют.

Менее изученная по сравнению с “большой коррупцией”, повседневная коррупция стала объектом новаторского для Африки антропологического исследования (Blundo, Olivier de Sardan 2006a), выполненного в русле этнографического поворота, в центре которого - наблюдение за функционированием государства в конкретных ситуациях, за деятельностью различных органов власти и распределением в обществе товаров и услуг ${ }^{7}$. В ходе исследования удалось выявить “элементарные формы коррупции” в Сахеле, создающие континуум, идеально соединяющий два диаметрально противоположных в общественном мнении полюса: от сделки до вымогательства и частного присвоения государственных ресурсов.

К коррупции в форме сделки можно отнести различные комиссионные, которые чиновники получают за посредничество или незаконно оказанные услуги. Будучи в порядке вещей в секторе государственных закупок, где коррупция имеет вид “цивилизованной” и почти законной (Blundo 2006c), комиссионные в денежной или натуральной форме могут также выплачиваться вышестоящему начальству за назначение на хлебные должности. В судах, ЗАГСах, больницах принято и даже считается законным отблагодарить госслужащего за хорошее исполнение им своих обязанностей, что стирает грань между добровольным подарком в знак благодарности и обязательной взяткой. Существуют также подарки авансом, цель которых - поставить госслужащего в положение должника по отношению к своему “благодетелю”. Напротив, неправомерные платежи за услуги, которые должны быть бесплатными, - например, взимание двойной цены за медицинскую карту работником регистратуры в диспансере, или продажа бланков и другой печатной продукции, дефицит которых создается искусственно, находятся на грани вымогательства, поскольку в данном случае никакая услуга реально не оказывается. 
Самым известным примером является рэкет с помощью блокирования дорог, жертвами которого становятся таксисты и водители грузовиков. Большое количество блокпостов выставляется незаконно различными структурами (полицией, жандармерией, таможней, службой водного и лесного хозяйства, муниципалитетами, иммиграционными службами, профсоюзами) и препятствует свободному перемещению товаров, в особенности в анклавных странах - Нигере, Буркина-Фасо и Мали. В последней стране в 2013 г. насчитывалось в среднем 2,6 контрольных пункта на каждые 100 км. Рэкет на дорогах приносит в этих трех странах сверхдоходы, оцениваемые в сумму от 12 до 23 млн евро в год и создает ежегодные потери времени от 1104 до 2103 месяцев (Banque Africaine de Développement 2015: 16-22). В странах, где государство действует особенно жестко, как в Чаде, дело доходит до того, что рэкету подвергается даже миротворческая миссия $\mathrm{OOH}$ - нанимаемые ею работники были обложены “данью”, превышающей 40\% их месячной зарплаты (Debos 2013: 63).

С другой стороны, мы встречаем практики, которые нелегко отличить от обычной социальности. В эту категорию входят взаимные услуги и одолжения между бывшими соучениками, родственниками, земляками, однопартийцами. В подобных случаях государственный служащий оказывается перед непростым выбором: действовать согласно абстрактной и редко практикуемой в его профессиональной среде бюрократической этике - или же сохранить верность личным, семейным или политическим связям. Здесь представления чиновников и обычных людей не сильно отличаются, поскольку каждый, кто откажется прийти на выручку близкому человеку, рискует навлечь на себя общественное порицание и подвергнуться остракизму. Растраты и использование государственного имущества в личных целях также давно стали обычным делом: частные поездки на служебных машинах и разговоры по служебным телефонам; продажа “налево" медикаментов из больниц и диспансеров; нелегальные подключения к водопроводным и электрическим сетям мэрии; массовые хищения государственных средств, иногда осуществляемые целыми сетями сообщников.

\section{Коррупция и бюрократическое управление}

В Сахеле эти практики мелкой коррупции подпитываются - и подпитывают его в свою очередь - всеобщим разладом государственных служб, существенно ослабленных структурной перестройкой, которая резко сократила людские и материальные ресурсы административных органов, не улучшив при этом их эффективность и внутреннюю управляемость. Ситуацию усугубляет растрата в верхах и без того скромных бюджетов этих служб.

Последствия для чиновников оказались катастрофическими: роль фаворитизма и клиентелизма в назначении на посты и продвижении по службе усилилась, управление людскими ресурсами стало восприниматься повсюду как “беззаконное, произвольное, безжалостное, а то и бесчеловечное" (Blundo 2011a: 392). Конкуренция за доступ к хлебным местам (открывающим возможность быстрого карьерного роста, доступ к рынку проектов развития или к незаконному обогащению) в администрации возросла, тогда как малодоходные должности, рассматриваемые как тупиковые, бесперспективные, достаются чиновникам, не имеющим высокой поддержки, или становятся местом искупления за административные проступки.

Нехватка чиновников восполняется наймом целой когорты помощников - “добровольных" или контрактников: это ведет к прекаризации и неформальной приватизации государственной администрации (Blundo 2006b). В Нигере на 26 тыс. чиновников приходится около 40 тыс. таких помощников (Lavigne Delville, Abdelkader 2010: 59), немало их и в других странаx. 
В больницах, судах, министерствах они выступают в роли административных брокеров, облегчая и одновременно фильтруя доступ посетителей к непрозрачным и скрытым государственным услугам. Тем самым они способствуют приданию государственной службе “неформального” характера и нередко выступают проводниками мелкой коррупции.

К недостаточности людских ресурсов добавляется хроническая нехватка - структурная или намеренно создаваемая - необходимых для нормальной работы средств: можно упомянуть недостаток горючего или служебного оружия у бригад лесников в Нигере или Сенегале, а также тот факт, что в $86,7 \%$ санитарных учреждений Нигера нет электричества, воды и туалетов (Banque Mondiale 2015). На фоне этой крайней бедности административных служб выделяются несколько “островков благополучия" - бюрократические анклавы, создаваемые или питаемые системой международной помощи, которые переманивают лучших чиновников, предоставляя им условия, разительно отличающиеся от того, что могут предложить “обычные” административные службы. Такая “двухуровневая администрация” (Blundo 2011с) усугубляет разочарование служащих и подталкивает их к двум типам поведения. Первый - упорная гонка за материальными “поощрениями” (Smith 2003, Ridde 2012), надбавками к базовому окладу, работа на две, а то и три ставки, организация мелкой торговли на рабочем месте. Это одна из основных причин частого отсутствия служащих на работе, затрагивающего такие важные сферы, как образование и здравоохранение: все в том же Нигере ежедневно 33\% медицинского персонала не выходит на службу, а 27\% учителей отсутствуют в классах (Banque Mondiale 2015).

Другой тип поведения - неформальная приватизация административных служб, часто с целью восполнить их недостаток. Так, чиновники обращаются с должностями, как со своей собственностью: они вкладывают личные средства в служебную деятельность и при этом получают от нее выгоду. В службах контроля и безопасности, например, вполне обычным делом является реинвестирование части ежедневно получаемых взяток в подержание в порядке рабочего снаряжения или в решение семейных проблем сотрудников.

Для потребителей структурная перегрузка административного аппарата выливается в длинные очереди за любой простейшей услугой. “Денежный ускоритель” вызывают к жизни многочисленные узкие места, медлительность и задержки при контактах с администрацией в приемных покоях больниц, контрольных пунктах лесничеств или в жандармерии, если нужно растаможить контейнер.

Обращение сотрудников администрации с посетителями бывает разным: игнорируемые, презираемые или даже подвергающиеся плохому обращению, если у них нет контактов внутри той или иной службы, они становятся достойными внимания, когда прибегают к помощи денег или знакомств. Часто мелкая коррупция становится первым шагом к установлению устойчивых личных отношений между посетителем и чиновником. Эта бюрократическая среда, которую мы обрисовали в основных чертах, “увенчана” двумя пересекающимися политико-административными логиками: фракционностью и интервенционизмом.

Фракционность. Фракционный тип политической конкуренции существует в Сахеле веками и при любых политических системах. В Сенегале он является двигателем национальной политической жизни начиная с эпохи Четырех Коммун вплоть до периода правления Абдулая Вада (Legros 2004), включая годы социалистического режима (Fatton 1986, Blundo 1998). Близкие формы мы встречаем в Нигере (Olivier de Sardan 2017), Чаде и Мавритании, где фракционность принимает племенные коннотации (Blundo 2011b). От деревенских вождей до верхушки государственного аппарата межфракционная борьба порождает высоко персонализированную 
политическую игру, основанную на временных и изменчивых альянсах (феномен т. наз. политического “кочевничества”, когда сторонники покидают поверженного политического лидера и переходят на сторону победителя), управление общественными делами в режиме краткосрочной перспективы, стратегии борьбы, нарушающие формальные правила политического соперничества, действия в узкогрупповых интересах в ущерб более широкому сообществу и в особенности - хищническую логику перераспределения, согласно которой эфемерную добычу следует быстро ухватить и разделить исключительно внутри властной клики. Фракционность, порождая общественные представления, ассоциирующие политику с обманом, интригами, предательством и уловками, усиливает недоверие граждан к политической деятельности и питает мелкую и крупную коррупцию.

Интервенционизм и множественная ответственность. Вопреки обыденному представлению, распространяемому экспертами в сфере good governance и объясняющему расцвет коррупции в Африке недостатком ответственности государственных служащих, недавние исследования заставляют предположить, что чиновники в Сахеле, напротив, отягощены избытком ответственности (Blundo 2015a), поскольку в исполнение ими своих повседневных обязанностей, а также в соблюдение законов и установлений постоянно вмешиваются различные формальные и неформальные институты и действующие лица, выступающие в роли посредников между гражданами и государством. Это вмешательство, являющееся прямым следствием выраженной персонализации и политизации административных отношений, стало обыденной стратегией укрощения государственной власти. Местные депутаты, традиционные вожди, высокопоставленные чиновники, министры, религиозные власти, бывшие одноклассники и однокурсники, коллеги, члены одного молитвенного собрания - это те люди, к которым считается естественным обратиться, чтобы не платить штраф, освободить задержанного, отменить нежелательное назначение на службу, выиграть местный конкурс и т.п. Этот список, далеко не исчерпывающий, демонстрирует распространенность и многообразные формы обязательств, которым подчинены бюрократы и политики при исполнении своих функций. Многопартийность лишь усугубила логику интервенционизма, которая ставит чиновников, особенно невысокого ранга, в зависимость от противоречивых вмешательств (Bierschenk 2014), поскольку вышестоящее начальство требует от них одновременно исполнения законов и их нарушения. Такая система также препятствует любым попыткам применения санкций против государственных служащих, совершивших профессиональные проступки или допустивших растрату. В ответ чиновники применяют различные стратегии, от поиска могущественного покровителя до исключительной осторожности, следствием которой становится отсутствие какой-либо инициативы и бездеятельность, не останавливаясь и перед коррупционными действиями.

\section{Борьба с коррупцией}

Противоречивые представления: от терпимости до стигматизации. С первых лет независимости общество в Сахеле не перестает проклинать коррупцию. Отражения этого можно найти в литературе или народном театре: в знаменитой повести "Мандат" Сембена Усмана главный герой, блуждающий в бюрократических коридорах Дакара 1960-х гг., встречает людей, жалующихся, что в Сенегале, где “честность является преступлением”, трудно получить услугу, не “подмазав", не обратившись к кому-то влиятельному или не “раздвинув ноги" (Ousmane 1966). Почти полвека спустя комедия в духе традиционного малийского театра “котеба” бичует разъедающие страну бесхозяйственность и несправедливость. Коррупция вызывает также массовые протесты, как например восстание крестьян-муби в Республике Чад в 1964 г. против 
злоупотреблений и рэкета со стороны администрации (Arditi 2000) или демонстрации с требованием наказать виновных в экономических и политических преступлениях режима М. Траоре в Мали (Lange 1999: 123). То же стремление к оздоровлению политических нравов выражало в Сенегале конца 1980-х гг. движение Set setal (“очистить” на языке волоф) (Diouf 1992).

Таким образом, сахельские общества небезразличны к нарушениям общественной нравственности. Как же тогда объяснить всепроникающий парадокс коррупции, единодушно критикуемой, но в то же время терпимой и повседневно практикуемой? Прежде всего, коррупция - это самовоспроизводящийся феномен. В ситуации, когда практически каждый человек непосредственно или опосредованно имел с ней дело, вера в то, что доступ к товарам и услугам либо может быть монетизирован, либо ограничен кругом родственников, друзей и знакомых, подталкивает всех и каждого к защите от коррупции “других" путем применения ее в качестве превентивной меры, создавая тем самым порочный круг (Blundo, Olivier de Sardan 2006a: 105-106).

Во-вторых, в Сахеле существуют постколониальные социальные логики, ведущие к легитимации коррупционного поведения: большая часть общественных отношений опосредована деньгами, расточительность культивируется элитами как добродетель, и по этому критерию их оценивает клиентела. Поэтому некоторые формы внезапного обогащения, хоть и предосудительные с юридической точки зрения, могут считаться допустимыми при условии дальнейшего перераспределения, пусть даже символического, добытого нечестным путем, тогда как обычный человек, пойманный с поличным на воровстве, рискует стать жертвой скорого на расправу народного суда.

В целом коррупция в Сахеле “настолько у всех на виду, что она перестает считаться девиантным поведением и попадает в разряд морально приемлемых и даже в значительной степени одобряемых практик” (Blundo 2007: 34). Она становится формой соблюдения местного этикета (отказаться от подарка невежливо, коллеги должны взаимно выручать друг друга, нужно уважать старших), а также жестом мщения государству, которое не платит зарплаты и самоустранилось от простейших из своих функций, а также, возможно, своего рода подражательным поведением (зачем быть честным, если все сверху донизу коррумпированы?) (Blundo, Olivier de Sardan 2006b).

Можно даже говорить о дискредитации честности: доносы заклеймены, а обладатели доходных мест, не сумевшие ими воспользоваться для собственного обогащения, презираемы. Новая этика преуспеяния возводит в ранг ценности то, что в Мавритании называют tcheb-tchib - термин, обозначающий обход закона с помощью хитрости с целью получения личной выгоды (Ould Ahmed Salem 2001). Мы уже писали о том, что в Сахеле “добродетель абсолютной честности является роскошью, недоступной большинству граждан” (Blundo, Olivier de Sardan 2006а: 100).

“Автономные” инициативы государств Сахеля по борьбе с коррупцией. С момента обретения независимости государства Сахеля создали у себя органы и законодательные механизмы, позволяющие контролировать и наказывать противозаконные практики в административных структурах.

На общем фундаменте колониального уголовного кодекса каждая страна выстроила собственные инструменты борьбы с коррупцией в соответствии с конкретной политической ситуацией. Все они располагали “обычными” органами внутреннего и внешнего контроля, а именно техническими инспекциями внутри каждого министерства, генеральными государственными и финансовыми инспекциями, а также различными комиссиями, такими 
как Комиссия по проверке и контролю счетов государственных предприятий (CVCCEP) в Сенегале. Однако опыт Нигера, Сенегала и Мавритании (Mathieu 2007a, Blundo 2011b) показал ограниченность возможностей этих компетентных и хорошо оплачиваемых контролирующих органов: они действуют только а posteriori, не могут инициировать проверки, их сменяют при смене режима, а их доклады кладутся под сукно президентом или премьер-министром и остаются без последствий. Можно отметить все же, что в случаях больших потрясений в верхах или кризиса легитимности власти исполнительные органы создают чрезвычайные комиссии, становящиеся символами новой политической эры (Mathieu 2007a). Так, в Сенегале Абду Диуф дистанцировался от верхушки партии своего предшественника на президентском посту Леопольда Седара Сенгора, приняв в 1980 г. закон о борьбе с неправомерным обогащением. Замороженный два года спустя, этот закон имел своим результатом лишь два приговора к тюремному заключению и несколько штрафов. Сыгравший важнейшую роль в демократической смене власти в стране Абдулай Вад в 2000 г. начал проверки множества национальных компаний, а в 2003 г. создал Национальную комиссию по борьбе с непрозрачностью, коррупцией и хищениями. Сменивший его на президентском посту Маки Сал заменил эту комиссию двумя новыми структурами: Национальным управлением по борьбе с мошенничеством и коррупцией и Национальной комиссией по реституции и возвращению активов, полученных неправедным путем. Но самое главное - он восстановил действие закона о неправомерном обогащении, по которому сын уходящего президента Карим Вад был приговорен к 6 годам тюремного срока и 210 млн евро штрафа.

В Нигере также хроническая политическая нестабильность привела в период с 1974 по 2000 гг. к созданию и последующему роспуску 8 различных комиссий. В годы своего чрезвычайного правления президент Сейни Кунче создал экономическую полицию и специальный суд, которые карали хищение государственных средств пожизненным заключением или смертной казнью (Amuwo 1986, Mathieu 2007a).

Более точечные операции “сильного удара" позволяют продемонстрировать - лишь на время - нулевую терпимость к преступникам в белых воротничках и организовать избирательные чистки политико-административных конюшен. Так было, например, в ходе антикоррупционной операции "Кобра" в Республике Чад в 2012 г., которая дала весьма неоднозначные результаты: сумма возвращенных в бюджет средств составила лишь одну двенадцатую часть похищенного (по оценкам - 300 млрд. африканских франков в год), а обвиненные в хищениях чиновники в большинстве своем были просто переведены на другие посты (Debos 2013: 51, Chêne 2014: 8).

Двусмысленная роль доноров. В контексте глобализации борьбы с коррупцией невозможно обойти стороной роль международных фондов. Их позиция выглядит двусмысленной, особенно после Парижской декларации по повышению эффективности внешней помощи (2005 г.), провозгласившей, что условия построения эффективных систем общественной честности должны соответствовать приоритетам и процедурам государств - получателей помощи. Между тем доноры навязывают создание стандартизованных механизмов предупреждения коррупции и борьбы с ней, зачастую без учета того, что они дублируют функции уже существующих структур. Так, по указанию Программы развития ООН в 2001 г. в Буркина-Фасо был создан Высший координационный совет по борьбе с коррупцией (HACLCC), чьи компетенции пересекаются с созданным незадолго до того Национальным этическим комитетом. Лишенный реальной власти и малопрозрачный HACLCC в 2007 г. был объединен, также под давлением доноров, с Национальным координационным советом по борьбе с мошенничеством и Генеральной государственной инспекцией в единый Высший орган государственного контроля (Damiba 2008: 
$49,79)$. Напомним также, что запоздалое создание счетных палат - высшего органа, контролирующего государственные финансы ${ }^{8}$, также в основном вызвано настоянием Западноафриканского экономического и валютного союза и международных доноров.

В целом условия, навязанные международными донорами, привели к невыразительным, а то и откровенно контрпродуктивным результатам, как показывает проект нефтепровода Чад - Камерун. Целью этого проекта, начатого в 2000 г., было добиться, чтобы доходы от добычи нефти в Республике Чад шли на борьбу с бедностью. Вплоть до 2005 г. Коллегия по контролю и надзору над нефтяными ресурсами играла свою роль, однако в следующем году президент Идрис Деби изменил закон таким образом, чтобы средства от добычи нефти было можно тратить на покупку оружия и подавление внутренних беспорядков. Всемирный банк, поддерживавший проект, вышел из него окончательно в 2008 г. признав, что он способствовал усилению коррупции (Winters and Gould 2011: 242, Chêne 2014: 7).

В Сахеле, где царит лицемерие, велика разница между официальными встречами, на которых рассуждают о good governance, и непрозрачностью, характеризующей реальное распределение государственных ресурсов. Можно иметь репутацию “прилежных учеников”, выполняющих все рекомендации доноров, систематически фальсифицируя национальные макроэкономические показатели, как это делают Буркина Фасо и Мавритания (Samuel 2011). К тому же принуждение к честности со стороны доноров, похоже, работает только в интересах их собственных программ9 : для предотвращения растраты выделяемой финансовой помощи они создали параллельные контролирующие структуры, нарушающие нормальное функционирование администрации стран-получателей (Blundo 2015b) и маскирующие их собственную роль в провоцировании и способствовании местной коррупции (Mathieu 2000, Mathieu 2007b). В конечном счете различные законодательные и институциональные меры, как эндогенные, так и экзогенные, принятые на рубеже XXI в. в Сахеле, оказались неэффективными либо вследствие нехватки людских и финансовых ресурсов для ведения расследований; либо из-за зависимости контролирующих органов от исполнительной власти; либо по причине недостаточной координации: введение новых механизмов борьбы с коррупцией без отмены старых в результате парализовало и те, и другие; либо из-за несоответствия международных норм в сфере борьбы с коррупцией местным условиям ${ }^{10}$.

Общественные движения и брокеры good governance. Социальные запросы на большую честность в обществе разнородны, плохо скоординированы и амбивалентны. Первыми сформулировали их студенческие и рабочие профсоюзы: в Буркина Фасо, Нигере и Сенегале они уже давно находятся в авангарде разоблачения коррупции, в частности, на таможне, дорожных блокпостах и в сфере госзакупок (Blundo 2006c, Mathieu 2007a, Damiba 2008). Даже профсоюзы “людей в униформе”, не славящихся особой порядочностью, порой восстают против крупной коррупции власть имущих. Так, в Нигере в 1990-х гг. Единый профсоюз работников водного и лесного хозяйства пытался безуспешно бороться против саудовского принца Бандара, безнаказанно браконьерствовавшего в лесах Нигера при попустительстве высших государственных и армейских чинов (Grégoire 2000). Что касается предпринимателей, то они пытаются защититься только от той коррупции, которая вредит им экономически: профессиональные организации - как, например, общества транспортников в Нигере или торговцев в Сенегале - порой жестко критикуют рэкет полиции или таможенников, практикуя при этом различные формы договоренностей с властями.

Возникшие на рубеже XXI в. движения городской молодежи, вышедшие из культуры хип-хопа, требованиями морального оздоровления сенегальской общественной жизни во мно- 
гом способствовали как падению в 2000 г. Социалистической партии (поколение Bul faale ${ }^{11}$ ), так и отставке Абдулая Вада в 2012 г. (движение Y'en a marre ${ }^{12}$ ) (Dieng 2015). Эти инициативы стали источником вдохновения для движения “Гражданская метла", возглавившего революцию в Буркина Фасо в октябре-ноябре 2014 г. (Hagberg et al. 2015).

Растет и роль диаспоры. В Сенегале эмигранты, имеющие влияние благодаря регулярным денежным переводам, отправляемым в родные деревни и идущим на коллективные нужды (водяные скважины, школы), активно участвуют в местной общественной жизни и разоблачают коррупцию представителей власти, которых иногда удается привлечь к ответственности (VariLavoisier 2014).

Наконец, новые действующие лица, которых можно назвать “брокерами good governance” (Blundo 2012), превращаются в официальных, профессиональных и необходимых представителей так называемого “гражданского общества” в Сахеле. Речь идет о появившихся во второй половине 1990-х гг. НПО и различных ассоциациях, которые участвуют в национальной политической жизни, по-своему переосмысляя международные стандарты общественной честности и ставя своей основной целью пересмотр отношений между гражданами и государственной властью. Конечно, попутно они претендуют на часть финансовых доходов от антикоррупционной индустрии. Показателен пример "Гражданского форума" - сенегальской ассоциации, основанной в 1993 г. выходцами из среды юристов и либеральных профессий и ставшей в 2000 г. сенегальским отделением международной организации Transparency International ${ }^{13}$, а затем одним из наиболее влиятельных игроков на поле борьбы с коррупцией в Африке.

Однако эти зачатки “глокальных” гражданских движений распространяют элитарные представления, с трудом укореняющиеся на местной почве. Если в Сенегале или Буркина Фасо их интересы в чем-то сходятся с республиканскими установками некоторых религиозных деятелей католической церкви или суфийского ислама (Management Systems International 2007, Hagberg et al. 2017), то реформистские исламские движения ваххабитского толка, выступающие с радикальной критикой государственных учреждений и желающие реформировать их в соответствии с шариатом (квиетисты) (Sounaye 2016) или вовсе установить халифат (джихадисты-салафиты), составляют им конкуренцию, особенно в Мали и Нигере.

\section{Конец договорной вседозволенности?}

В Сахеле, где коррупция достигла небывалого прежде уровня, она была на протяжении десятилетий инструментом и формой общественного договора, характеризуемого как “вседозволенность” (Nugent 2010) и обеспечивавшего соблюдение определенного порядка. Однако есть множество признаков того, что эта система себя исчерпала. С одной стороны, миф о том, что коррупция является альтернативной формой перераспределения богатств, развеялся в глазах населения, ежедневно сталкивающегося с невозможностью получить базовые государственные услуги, а также страдающего от деградации экономики и окружающей среды. С другой стороны, очевидна связь между административной и политической коррупцией, организованной преступностью (торговля оружием, наркотиками и людьми) и терроризмом в регионе с огромными пустынными пространствами, плохо контролируемыми такими государствами, как Нигер, Мавритания и Мали, ослабленными регулярными политическими кризисами (Djallil 2013, Harman 2014). Так, с виду невинная коррупция на контрольно-пропускных пунктах на границе между Нигером и Нигерией угрожает безопасности региона, поскольку взятки делают границу легко проходимой как для мелких торговцев- контрабандистов, так и для криминальных или террори- 
стических группировок (Hahonou 2016). Точно также коррупция в армии и силовых структурах Мали делает невозможным обмен разведданными, необходимый для борьбы с вооруженными группировками, бесчинствующими на севере страны с 2012 г. (Cantens, Raballand 2016: 13).

Борьба с всеобщей коррупцией, ставшей способом управления людьми и ресурсами, остается делом сложным и долгим, для которого необходимо сочетание реальной политической воли и общественного запроса, располагающего адекватными возможностями для формирования и выражения. На данный момент, похоже, эти условия отсутствуют, но без них ничего не получится. Под давлением общественного мнения, становящегося в условиях затяжного экономического кризиса все более враждебным к расхищению государственных средств, а также международных организаций, ставящих оказание финансовой помощи в зависимость от порядочности и честности в общественных делах, пространство для маневра правителей большинства государств Сахеля, пытающихся балансировать между борьбой с коррупцией и сохранением собственной власти, сжимается, как шагреневая кожа. 


\section{Примечания}

1 В этой статье мы используем широкое и ненормативное определение коррупции, понимаемой как совокупность “практик, связанных с ненадлежащим использованием государственной должности (...) и приводящих к неоправданной личной выгоде” (Blundo, Olivier de Sardan 2006c: 5-6).

2 Приблизительно тот же рейтинг дает Mo Ibrahim Index of African Governance (Mo Ibrahim Foundation 2016).

3 Колониальная власть была организована по-разному в сахаро-сахельской зоне Мавритании, Чада, Нигера и Мали, где было установлено своего рода косвенное управление à la française, и в южных районах тех же стран, в Буркина-Фасо и тем более в Сенегале, где с конца XIX в. граждане Четырех Коммун активно участвовали в местной политической жизни.

${ }^{4}$ Пусть и недостаточно профессиональной, зачастую ангажированной и несвободной от тех же самых недостатков, которые она обличала.

5 Данные по Нигеру см.: Tidjani Alou 2001. Обзор сенегальской прессы за период 1974-2000 гг. выявил, что 60\% статей о коррупции были опубликованы в 1990-е гг. См. Blundo 2001с.

6 Национальные конференции проходили в странах Сахеля, за исключением Буркина Фасо и Сенегала, с 1991 по 1993 гг.

7 Существуют исследования налоговых и таможенных служб (Bako Arifari 2006, Dieye 2008), правосудия (Tidjani Alou 2006, Fomba 2014, Hamani 2014b), здравоохранения (Masquelier 2001, Jaffré, Olivier de Sardan 2003, Foley 2010, Hahonou 2015), образования, государственных закупок (Blundo 2001a, Blundo 2006c), управления лесными и иными природными ресурсами (Benjaminsen, Ba 2009), земельной собственности в городах (Choplin 2006) и сельской местности (Воији 2009), военизированных формирований (Beek and Göpfert 2013, Blundo and Glasman 2013, Göpfert 2016b, Göpfert 2016a), транспорта (Cissokho 2017).

8 За исключением Мавритании, где Контрольная палата была создана в 1992 г., в остальных государствах региона соответствующие органы были созданы между началом (Сенегал и Буркина Фасо, 2000 г.) и вторым десятилетием XXI в. (Нигер 2012, Чад 2015). До сих пор нет Контрольной палаты в Мали.

9 Широкое распространение бюджетной поддержки создало новые возможности для хищений, как показало “дело Министерства общего образования и распространения грамотности” (фр. МЕВА), наделавшее шуму в Нигере в 2005 г., когда обнаружилась “дыра” почти в 5 млрд африканских франков, выделенных Министерству Евросоюзом (Hamani 2014a: 16).

${ }^{10}$ Отметим, что хотя все государства Сахеля ратифицировали Конвенции ООН и Африканского Союза по борьбе с коррупцией, принятые в 2003 г., их кодификация в национальном законодательстве и инструменты имплементации вызывают вопросы (OCDE 2018). Что касается Протокола Экономического сообщества государств Западной Африки (CEDEAO) о демократии и хорошем управлении (который касается четырех из шести стран региона) хоть он и поддержан на бумаге Сетью национальных антикоррупционных институтов Западной Африки, но остается абсолютно бездейственным из-за отсутствия финансирования (Badet et al. 2016: 20).

11 “Не парься” (волоф) - прим. перев.

12 “Нам надоело” (фр) - прим. перев.

13 Представителем Transparency International в Нигере является Нигерийская ассоциация по борьбе с коррупцией (ANLC/TI), а в Мали - Информационно-аналитический центр по укреплению демократии.

Пер. с фр. Е.И. Филипповой

\section{Источники и материаль}

Banque Africaine de Développement 2015. Problématique de la facilitation du transport en Afrique de l'Ouest et Plan d'actions. Département des Transports du Développement Urbain et des TIC.

Banque Mondiale 2015. Niger. Indicateurs de prestation de service 2015. Rapport technique sur la santé. Services Délivery Indicators.

Chêne, M. 2014. Overview of Corruption and Anti-Corruption in Chad. Anti-Corruption Helpdesk. Berlin: Transparency International. 
Management Systems International 2007. Evaluation de la corruption au Sénégal.

Mo Ibrahim Foundation 2016. A Decade of African Governance 2006-2015. 2016 Ibrahim Index of African Governance.

OCDE 2018. Flux financiers illicites: L’économie du commerce illicite en Afrique de l'Ouest. Paris: Éditions OCDE.

Ousmane, S. 1966. Le mandat. Présence africaine.

\section{Научная литература}

Amuwo K. Military-Inspired Anti-Bureaucratic Corruption Campaigns: An Appraisal of Niger's Experience // Journal of Modern African Studies. 1986. Vol. 24 (2): 285-301.

Arditi C. Du "prix de la kola" au détournement de l'aide internationale: clientélisme et corruption au Tchad (1900-1998) // Monnayer les pouvoirs. Espaces, mécanismes et représentations de la corruption / Ed. G. Blundo. Paris: PUF, 2000. P. 249-267.

Badet G., Damiba, L., Engueléguélé, S.B., Gaima, E., Iwuamadi, C.K. Ndiaye, S., Williams, S. 2016. Effectivité des agences nationales anti-corruption en Afrique de l'ouest. Bénin, Libéria, Niger, Nigéria, Sénégal, Sierra Leone. New York: Open Society Foundation.

Bako Arifari N. 2006. We don't Eat the Papers: Corruption in Transport, Customs and the Civil Forces // Everyday Corruption and the State. Citizens and Public Officials in Africa / Eds. G. Blundo, J. P. Olivier de Sardan. London: Zed Books, 2006. P. 177-224.

Bayart J.-F. L'Etat en Afrique. La politique du ventre. Paris: Fayard, 1989.

Beek J., Göpfert M. State Violence Specialists in West Africa // Sociologus. Journal for Empirical Social Anthropology. 2013. Vol. 63 (1-2). P. 103-124.

Benjaminsen T. A., Ba B. Farmer-herder conflicts, pastoral marginalisation and corruption: a case study from the inland Niger delta of Mali // The Geographical Journal. 2009. Vol. 175 (1). P. 71-81.

Bierschenk T. Sedimentation, Fragmentation and Normative Double-Binds in (West) African Public Services // States at Work. Dynamics of African Bureaucracies / Eds. T. Bierschenk, J. P. Olivier de Sardan. Leiden: Brill, 2014. P. 221-248.

Blundo G. Logiques de gestion publique dans la décentralisation sénégalaise: participation factionnelle et ubiquité réticulaire // Bulletin de l’APAD. 1998. $\mathrm{n}^{\circ}$ 15. P. 21-47.

Blundo G. "Dessus de table". La corruption dans la passation des marchés publics locaux au Sénégal // Politique Africaine. 2001. n 83. P. 79-97.

Blundo G. La corruption comme mode de gouvernance locale: trois décennies de décentralisation au Sénégal // Afrique Contemporaine. 2001. n 199. P. 106-118.

Blundo G. La corruption quotidienne au Sénégal // La corruption au quotidien en Afrique de l'Ouest. Approche socio-anthropologique comparative: Bénin, Niger et Sénégal / Eds. G. Blundo, J. P. Olivier de Sardan. Marseille: EHESS, IUED, IRD, 2001. P. 173-236.

Blundo G. Corruption in Africa and the social sciences: a review of the literature // Everyday Corruption and the State. Citizens and Public Officials in Africa / Eds. G. Blundo, J.-P. O. de Sardan. London: Zed Books, 2006. P. 15-68.

Blundo G. Dealing with the Local State: The Informal Privatization of Street-Level Bureaucracies in Senegal // Development \& Change. 2006. Vol. 37 (4). P. 799-819.

Blundo G. An ordered corruption? The social world of public procurement // Everyday corruption and the State. Citizens and public officials in Africa / Eds. G. Blundo, J. P. Olivier de Sardan. London: Zed Books, 2006. P. 225-262.

Blundo G. Hidden Acts, Open Talks. How Anthropology Can "Observe" and Describe Corruption / Corruption and the Secret of Law. A Legal Anthropological Perspective / Eds. G. Anders, M. Nuijten. Aldershot: 
Ashgate, 2007. P. 27-52.

Blundo G. Comme un ballon de foot. La gestion quotidienne des ressources humaines dans les services forestiers en Afrique de l'Ouest // Auf dem Boden der Tatsachen. Festschrift für Thomas Bierschenk / Eds. N. Schareika, E. Spies, P.-Y. L. Meur. Köln: Köppe Verlag, 2011. P. 377-94.

Blundo G. "Graisser la barbe". La corruption en Mauritanie vue par ses élites Une anthropologie entre pouvoirs et histoire // Conversations autour de l'œuvre de Jean-Pierre Chauveau / Eds. E. Jul-Larsen, P.-J. Laurent, P.-Y. Le Meur, E. Léonard. Uppsala-Paris-Marseille: APAD-IRD-Karthala, 2011. P. 449-476.

Blundo $G$. Une administration à deux vitesses. Projets de développement et construction de l'Etat au Sahel. Cahiers d'Etudes Africaines 2011. Vol. LI 2-3 (202-203). P. 427-452.

Blundo G. Glocal integrity. Good governance brokers and the appropriation of transnational anti-corruption policies in Senegal // Democracy at Large. NGOs, Political Foundations, Think Tanks and International Organizations / Ed. B. Pétric. Basingstoke: Palgrave Macmillan, 2021. P. 25-48.

Blundo $G$. The King is not a kinsman. Multiple accountabilities and practical norms in West African bureaucracies // Real Governance and Practical Norms in Sub-Saharan Africa. The game of the rules / Eds. T. De Herdt, J. P. Olivier de Sardan. London: Routledge, 2015. P. 142-159.

Blundo G. La coproduction du retard. Anthropologie de l'aide budgétaire au Cameroun et au Niger. Marseille, Paris: Prospective \& Coopération-AFD, 2015.

Blundo G., Glasman J. Introduction: Bureaucrats in Uniform // Sociologus. Journal for Empirical Social Anthropology. 2013 Vol. 63 (1-2). P. 1-9.

Blundo G., Olivier de Sardan J.-P. La corruption comme terrain. Pour une approche socioanthropologique // Monnayer les pouvoirs. Espaces, mécanismes et représentations de la corruption / Ed. G. Blundo. Genève, Paris: IUED, PUF, 2000.

Blundo, G., and J.-P. Olivier de Sardan. 2006a. Everyday corruption in West Africa. Everyday corruption and the State. Citizens and public officials in Africa. G. Blundo and J.-P. O. de Sardan. London: Zed Books, 69-109.

Blundo G., Olivier de Sardan J.-P. The popular semiology of corruption. Everyday corruption and the State. Citizens and public officials in Africa. London: Zed Books, 2006. P. 110-134.

Blundo G., Olivier de Sardan J.-P. Why should we study everyday corruption and how should we go about it? // Everyday corruption and the State. Citizens and public officials in Africa. Eds. G. Blundo, J.-P. Olivier d. Sardan. London: Zed Books, 2006. P. 3-14.

Воији J. La malédiction, l'honneur et la spéculation. Principes historiques de la propriété foncière en Afrique de l'Ouest. Bulletin de l'APAD. 2009. n²9-30.

Brunschwig H. Noirs et Blancs dans l’Afrique noire française. Paris: Flammarion, 1983.

Cantens T., G. Raballand "Une frontière très très longue, un peu difficile à vivre": le Nord du Mali et ses frontières. Recherches \& documents. Paris: Fondation pour la recherche stratégique, 2016.

Choplin A. Le foncier urbain en Afrique: entre informel et rationnel, l'exemple de Nouakchott (Mauritanie) // Annales de Géographie. 2006. Vol. 647: 69-91.

Cissokho S. Petits échanges entre amis. Remarques sur l'ambivalence des rapports routiniers entre fonctionnaires et usagers au Sénégal // Revue française de science politique. 2017. Vol. 67 (4). P. 631-651.

Damiba L. Les “entreprises" anti-corruption au Burkina Faso. Trajectoires, représentations et conflits. Master en études du développement. Genève: Université de Genève, 2008.

de Maria B. 2008. Neo-colonialism through measurement: a critique of the corruption perception index // Critical Perspectives on International Business. 2008. Vol. 4 (2-3). P. 184-202.

Debos M. La guerre des préfets. Répression, clientélisme et illégalismes d'État dans l'entre-guerres tchadien // Politix. 2013. $n^{\circ} 4$ (104). P. 47-65.

Dieng M. La contribution des jeunes à l'alternance politique au Sénégal: Le rôle de Bul faale et de Y'en a marre // African Sociological Review / Revue Africaine de Sociologie. 2015. Vol. 19 (2). P. 75-95. 
Dieye Ch. T. Les trajectoires de la corruption bureaucratique au Sénégal. Le cas des douanes. Thèse de doctorat en Etudes du développement, Institut des Hautes Etudes Internationales et du Développement, 2008.

Diouf M. Fresques murales et écriture de l'histoire. Le Set/Setal à Dakar // Politique Africaine. 1992. Vol. 46: $41-54$

Djallil L. Dr. Al Qaida au Maghreb Islamique et le trafic de drogue au Sahel // Maghreb - Machrek. 2013. n² (216). P. 111-128.

Fatton R. Clientelism and patronage in Senegal // African Studies Review. 1986. Vol. 29 (4). P. 61-78.

Fay C. La démocratie au Mali, ou le pouvoir en pâture. Cahiers d'Etudes Africaines. 1995. Vol. XXXV-1 (137). P. $19-53$.

Foley E. E. Your Pocket is What Cures You: The Politics of Health in Senegal. New Brunswick, NJ: Rutgers University Press, 2010.

Fomba M. Les magistrats de terrain au Mali. Entre sollicitations et stratégies institutionnelles d'évitement // Afrique Contemporaine. 2014. n 250. P. 84-85.

Göpfert, M. Repairing the law: The search for justice in the Nigerien gendarmerie // Theoretical Criminology. 2016. Vol. 20 (4). P. 446-461.

Göpfert M. Surveillance in Niger: Gendarmes and the Problem of "Seeing Things" // African Studies Review. 2016. Vol. 59 (2). P. 39-57.

Grégoire E. Les chasses du prince Bandar // Autrepart. 2000. n 16. P. 87-97.

Gueye M. Justice indigène et assimilation // AOF: réalités et héritages. Sociétés ouest africaines et ordre colonial, 1895-1960 // Eds. C. Becker, S. Mbaye, I. Thioub. Dakar: Direction des Archives du Sénégal, 1997. n 1 . P. $153-169$.

Hagberg S., Kibora L., Barry S., Gnessi S., Konkobo A. Transformations sociopolitiques burkinabè de 2014 à 2016. Perspectives anthropologiques des pratiques politiques et de la culture démocratique dans "un Burkina Faso nouveau". Uppsala: Uppsala Universitet, 2017.

Hagberg S., Kibora L., Ouattara F., Konkobo A. 2015. Au coeur de la révolution burkinabé // Anthropologie \& développement. 2015. $n^{\circ}$ 42. P. 199-224.

Hahonou E. K. Juggling with the norms. Informal payment and everyday governance of healthcare facilities in Niger // Real Governance and Practical Norms in Sub-Saharan Africa. The Game of the Rules / Eds. T. De Herdt, J. P. Olivier de Sardan. London, New York: Routledge, 2015. P. 123-141.

Hahonou E. K. Corruption, Insecurity and Border Control in Niger // DIIS Policy Brief, 2016.

Hamani $O$. Etude des dispositifs d'aide financière. Le cas du Niger. Marseille: Prospective et Coopération, 2014.

Hamani $O$. "We make do and keep going". Inventive Practices and Ordered Informality in the Functioning of the District Courts in Niamey and Zinder (Niger) // States at Work. Dynamics of African Bureaucracies / Eds. T. Bierschenk, J. P. Olivier de Sardan. Leiden: Brill, 2014. P. 145-173.

Harman S. A. Terror and Insurgency in the Sahara-Sahel Region: Corruption, Contraband, Jihad and the Mali War of 2012-2013. Farnham: Ashgate, 2014.

Harsch E. Accumulators and Democrats: Challenging State Corruption in Africa // The Journal of Modern African Studies. 1993. Vol. 31 (1). P. 31-48.

$J a c o b$ J.-P. Introduction à la thématique des rapports entre corruption et sociétés anciennes. Les particularités du tiers inclus // Morale et corruption dans les sociétés anciennes du Burkina (Bobo, Moaga, San et Winyé). Collectif. Ouagadougou: REN-LAC, 2001.

Jaffré Y., Olivier de Sardanc J.-P. (Eds.). Une médecine inhospitalière. Les difficiles relations entre soignants et soignés dans cinq capitales d'Afrique de l'Ouest. Paris: Karthala, 2003.

Lange M.-F. Insoumission civile et défaillance étatique: les contradictions du processus démocratique malien // Autrepart. 1999. $\mathrm{n}^{\circ}$ 10. P. 117-34.

Lavigne Delville Ph., Abdelkader A. A cheval donné, on ne regarde pas les dents. Les mécanismes et les impacts 
de l'aide vus par des praticiens nigériens. LASDEL. Etudes et Travaux, 2010. $\mathrm{n}^{\circ} 83$.

Legros $O$. Les tendances du jeu politique à Yeumbeul (banlieue est de Dakar) depuis "l'alternance" // Politique africaine. 2004. Vol. 96 (4). P. 59-77.

Magrin G. Rentes, territoire et développement. Que tout change pour que rien ne change? // Bulletin de l'Association de géographes français. 2010. Vol. 87 (1): 56-68.

Masquelier A. Behind the dispensary's prosperous facade: Imagining the state in rural Niger // Public Culture. 2001. Vol. 13 (2). P. 267-291.

Mathieu M. Projets de développement et corruption. Prédispositions et effets d'entraînement // Monnayer les pouvoirs. Espaces, mécanismes et représentations de la corruption / Ed. G. Blundo. Genève, Paris: IUED, PUF, 2000. P. 123-155.

Mathieu M. La lutte contre la corruption au Bénin, au Niger et au Sénégal. Etat et corruption en Afrique. Une anthropologie comparative des relations entre fonctionnaires et usagers (Bénin, Niger, Sénégal) / Eds. G. Blundo, J. P. Olivier de Sardan. Paris: APAD-Karthala, 2007. P. 317-346.

Mathieu M. "Une république autonome". La corruption au quotidien dans un programme de coopération au développement au Sénégal // Etat et corruption en Afrique. Une anthropologie comparative des relations entre fonctionnaires et usagers (Bénin, Niger, Sénégal) / Ed. G. Blundo, J. P. Olivier de Sardan. Paris: APAD-Karthala, 2007. P. 285-315.

Nugent P. States and Social Contracts in Africa // New Left Review. 2010. Vol. 63. P. 35-68.

Olivier de Sardan J. P. Les sociétés songhay-zarma (chefs, guerriers, esclaves, paysans...). Paris: Karthala, 1984.

Olivier de Sardan J. P. A moral economy of corruption in Africa // Journal of Modern African Studies. 1999. Vol. 37. P. 25-52.

Olivier de Sardan J. P. Etat, bureaucratie et gouvernance en Afrique de l'Ouest francophone. Un diagnostic empirique, une perspective historique // Politique Africaine. 2004. Vol. 96. P. 139-162.

Olivier de Sardan J. P. (Ed.) Elections au village. Une ethnographie de la culture électorale au Niger. Paris: Karthala, 2015.

Olivier de Sardan J. P. Rivalries of proximity beyond the household in Niger: political elites and the baab-izey pattern // Africa. 2017. Vol. 87 (1). P. 120-136.

Olivier de Sardan, J.-P., Tidjani Alou M. (Eds.). Les pouvoirs locaux au Niger. Tome 1: A la veille de la décentralisation. Paris: Codesria-Karthala, 2009.

Ould Ahmed Salem Z. "Tcheb-tchib" et compagnie. Lexique de la survie et figures de la réussite en Mauritanie // Politique Africaine. 2001. Vol. 82. P. 78-100.

Ould Cheikh A. W. La science au(x) miroir(s) du prince. Savoir et pouvoir dans l'espace arabo-musulman d'hier et d'aujourd'hui // Revue des mondes musulmans et de la Méditerranée. 2002. Vol. 101-102. P. 129-155.

Ridde $V$. Réflexions sur les per diem dans les projets de développement en Afrique // Bulletin de l'APAD. 2012. Vol. 34-36.

Samuel B. Calcul macroéconomique et modes de gouvernement: les cas de la Mauritanie et du Burkina Faso // Politique Africaine. 2011. Vol. 124. P. 101-126.

Sarassoro H. La corruption et l'enrichissement sans cause en Afrique aujourd'hui // Afrique Contemporaine. 1990. Vol. 4 (156). P. 195-206.

Smith D. J. Patronage, per diems and the "workshop mentality": The practice of family planning programs in southeastern Nigeria // World Development. 2003. Vol. 31 (4). P. 703-715.

Smith M. G. Historical and Cultural Conditions of Political Corruption among the Hausa // Comparative Studies in Society and History. 1964. Vol. 6 (2). P. 164-194.

Sounaye A. Islam et modernité. Contribution à l'analyse de la ré-islamisation au Niger. Paris: L'Harmattan, 2016.

Tidjani Alou M. La corruption quotidienne au Niger // La Corruption au quotidien en Afrique de l'Ouest. Ap- 
proche socio-anthropologique comparative: Bénin, Niger et Sénégal / Eds. G. Blundo, J.-P. Olivier de Sardan. Marseille: EHESS, IUED, IRD, 2001. P. 109-171.

Tidjani Alou M. Corruption in the legal system // Everyday corruption and the State. Citizens and public officials in Africa // Eds. G. Blundo, J. P. Olivier de Sardan. London: Zed Books, 2006. P. 137-176.

Touquet $C$. Quand la colonisation perpétua les rapports de pouvoir propres aux sociétés de cour // L'Homme et la société. 2010. Vol. 1 (175). P. 39-56.

Vari-Lavoisier I. The Circulation of Monies and Ideas between Paris, Dakar, and New York: The Impact of Remittances on Corruption. Center for Migration and Development Working Paper Series. 2014. Vol. 50.

Verschave F.-X. La Françafrique. Le plus long scandale de la République. Paris: Stock, 1998.

Verschave F.-X. Noir silence. Qui arrêtera la Françafrique? Paris: Les Arènes, 2000.

Winters M. S., Gould J.A. 2011. Betting on oil: The World Bank's Attempt to Promote Accountability in Chad // Global Governance. 2011. Vo. 17 (2). P. 229-245.

Rese a r c h A r ticle

Blundo, G. Corruption and the State in the Sahel [Korruptsiia i gosudarstvo v Sakhele]. Anthropologies, 2021, no 1, pp. 97-120 https://doi.org/10.33876/2782-3423/2021-1/97-120

\title{
(C) Institute of Ethnology and Anthropology RAS
}

Giorgio Blundo | https://orcid.org/***** |giorgio.blundo@ehess.fr| CNRS, Centre Norbert Elias, 2 rue de la Charité, 13002 Marseille, France

\section{Keywords}

Sahel, corruption, state, bureaucracy, clientelism, good governance, international aid donors, social movements

\begin{abstract}
Starting in the early 2000s, new means of measurement produced by the international anticorruption industry cast a rather unflattering light on the Sahelian countries, stigmatizing them for their lack of public integrity. In 2016 the best known of these tools, Transparency International's "Corruption Perception Index" ranked all Sahelian countries, excepting (barely) Senegal, as states with systemic corruption (a score lower than 43). Perceptions vary from country to country: Senegal and Burkina Faso are reputedly less corrupt than Mali and Niger; these two are, in turn, more virtuous than Mauritania, and even more so than Chad. These approaches, purely quantitative and decontextualized, shed little light on how corruption is socially and culturally embedded in everyday life. In contrast, this article is based on qualitative empirical studies and on the author's own research in Niger, Senegal, and Mauritania.
\end{abstract}

\section{References}

Amuwo, K. 1986. Military-Inspired Anti-Bureaucratic Corruption Campaigns: An Appraisal of Niger's Experience. Journal of Modern African Studies 24(2): 285-301.

Arditi, C. 2000. Du "prix de la kola" au détournement de l'aide internationale: clientélisme et corruption au Tchad (1900-1998) [From the "price of cola" to the misappropriation of international aid: patronage and corruption in Chad (1900-1998)]. Monnayer les pouvoirs. Espaces, mécanismes et représentations de la corruption. G. Blundo (ed.), Paris: PUF. 9: 249-267.

Badet, G., L. Damiba, S. B. Engueléguélé, E. Gaima, C. K. Iwuamadi, S. Ndiaye, and S. Williams. 2016. Effectivité des agences nationales anti-corruption en Afrique de l'ouest. Bénin, Libéria, Niger, Nigéria, Sénégal, Sierra Leone. [Effectiveness of national anti-corruption agencies in West Africa. Benin, Liberia, Niger, Nigeria, Senegal, Sierra Leone] New York: Open Society Foundation. 
Bako Arifari, N. 2006. We don't Eat the Papers: Corruption in Transport, Customs and the Civil Forces. Everyday Corruption and the State. Citizens and Public Officials in Africa. G. Blundo and J. P. Olivier de Sardan. London: Zed Books: 177-224.

Bayart, J.-F. 1989. L'Etat en Afrique. La politique du ventre. [The State in Africa. The politics of the belly] Paris: Fayard.

Beek, J. and M. Göpfert. 2013. State Violence Specialists in West Africa. Sociologus. Journal for Empirical Social Anthropology 63 (1-2): 103-124.

Benjaminsen, T. A. and B. Ba. 2009. Farmer-herder conflicts, pastoral marginalisation and corruption: a case study from the inland Niger delta of Mali. The Geographical Journal 175 (1): 71-81.

Bierschenk, T. 2014. Sedimentation, Fragmentation and Normative Double-Binds in (West) African Public Services. States at Work. Dynamics of African Bureaucracies. T. Bierschenk and J. P. Olivier de Sardan. Leiden: Brill, 221-248.

Blundo, G. 1998. Logiques de gestion publique dans la décentralisation sénégalaise : participation factionnelle et ubiquité réticulaire [Public management logics in Senegalese decentralization: factional participation and reticular ubiquity] Bulletin de l'APAD 15: 21-47.

Blundo, G. 2001a. "Dessus de table". La corruption dans la passation des marchés publics locaux au Sénégal. ["Under the table". Daily corruption in local public procurement in Senegal] Politique Africaine 83: 79-97.

Blundo, G. 2001b. La corruption comme mode de gouvernance locale: trois décennies de décentralisation au Sénégal [Corruption as a mode of local governance: three decades of decentralization in Senegal]. Afrique Contemporaine 199: 106-118.

Blundo, G. 2001c. La corruption quotidienne au Sénégal [Daily corruption in Senegal]. La corruption au quotidien en Afrique de l'Ouest. Approche socio-anthropologique comparative: Bénin, Niger et Sénégal. G. Blundo and J. P. Olivier de Sardan. Marseille: EHESS, IUED, IRD, 173-236.

Blundo, G. 2006a. Corruption in Africa and the social sciences: a review of the literature [Corruption in Africa and the social sciences: a review of the literature]. Everyday Corruption and the State. Citizens and Public Officials in Africa. G. Blundo and J.-P. O. d. Sardan. London: Zed Books, 15-68.

Blundo, G. 2006b. Dealing with the Local State: The Informal Privatization of Street-Level Bureaucracies in Senegal. Development \& Change 37(4): 799-819.

Blundo, G. 2006c. An ordered corruption? The social world of public procurement. Everyday corruption and the State. Citizens and public officials in Africa. G. Blundo and J. P. Olivier de Sardan. London: Zed Books, 225-262.

Blundo, G. 2007. Hidden Acts, Open Talks. How Anthropology Can "Observe" and Describe Corruption. Corruption and the Secret of Law. A Legal Anthropological Perspective. G. Anders and M. Nuijten. Aldershot: Ashgate, 27-52.

Blundo, G. 2011a. Comme un ballon de foot. La gestion quotidienne des ressources humaines dans les services forestiers en Afrique de l'Ouest [Like a soccer ball. The daily management of human resources in forestry services in West Africa]. Auf dem Boden der Tatsachen. Festschrift für Thomas Bierschenk. N. Schareika, E. Spies and P.-Y. L. Meur. Köln: Köppe Verlag, 377-94.

Blundo, G. 2011b. "Graisser la barbe". La corruption en Mauritanie vue par ses élites Une anthropologie entre pouvoirs et histoire ["Grease the beard". Corruption in Mauritania seen by its elites An anthropology between powers and history]. Conversations autour de l'œeuvre de Jean-Pierre Chauveau. E. Jul-Larsen, P.-J. Laurent, P.-Y. Le Meur and E. Léonard. Uppsala-Paris-Marseille: APAD-IRD-Karthala, 449-476.

Blundo, G. 2011c. Une administration à deux vitesses. Projets de développement et construction de l'Etat au Sahel [Two-tier administration. Development projects and state building in the Sahel]. Cahiers d'Etudes Africaines LI 2-3 (202-203): 427-452.

Blundo, G. 2012. Glocal integrity. Good governance brokers and the appropriation of transnational anti-corruption policies in Senegal. Democracy at Large. NGOs, Political Foundations, Think Tanks and International Organizations. B. Pétric. Basingstoke: Palgrave Macmillan, 25-48. 
Blundo, G. 2015a. The King is not a kinsman. Multiple accountabilities and practical norms in West African bureaucracies. Real Governance and Practical Norms in Sub-Saharan Africa. The game of the rules. T. De Herdt and J. P. Olivier de Sardan. London: Routledge, 142-159.

Blundo, G. 2015b. La coproduction du retard. Anthropologie de l'aide budgétaire au Cameroun et au Niger [The co-production of the delay. Anthropology of budget aid in Cameroon and Niger.]. Marseille, Paris: Prospective \& Coopération - AFD.

Blundo, G. and J. Glasman 2013. Introduction: Bureaucrats in Uniform. Sociologus. Journal for Empirical Social Anthropology 63(1-2): 1-9.

Blundo, G., and J.-P. Olivier de Sardan, 2000. La corruption comme terrain. Pour une approche socioanthropologique [Corruption as a field. For a socio-anthropological approach]. Monnayer les pouvoirs. Espaces, mécanismes et représentations de la corruption. G. Blundo. Genève, Paris: IUED, PUF.

Blundo, G., and J.-P. Olivier de Sardan. 2006a. Everyday corruption in West Africa. Everyday corruption and the State. Citizens and public officials in Africa. G. Blundo and J.-P. O. d. Sardan. London: Zed Books, 69-109.

Blundo, G., and J.-P. Olivier de Sardan 2006b. The popular semiology of corruption. Everyday corruption and the State. Citizens and public officials in Africa. G. Blundo and J. P. Olivier de Sardan. London: Zed Books, 110-134.

Blundo, G., and J.-P. Olivier de Sardan 2006c. Why should we study everyday corruption and how should we go about it? Everyday corruption and the State. Citizens and public officials in Africa. G. Blundo and J.-P. O. d. Sardan. London: Zed Books, 3-14.

Bouju, J. 2009. La malédiction, l'honneur et la spéculation. Principes historiques de la propriété foncière en Afrique de l'Ouest [The curse, honor and speculation. Historical principles of land ownership in West Africa]. Bulletin de l'APAD 29-30.

Brunschwig, H. 1983. Noirs et Blancs dans l'Afrique noire française [Blacks and Whites in French Black Africa]. Paris: Flammarion.

Cantens, T.and G. Raballand 2016. "Une frontière très très longue, un peu difficile à vivre”: le Nord du Mali et ses frontières. Recherches et documents ["A very very long border, a little difficult to live with ": the North of Mali and its borders. Research and documents]. Paris: Fondation pour la recherche stratégique.

Choplin, A. 2006. Le foncier urbain en Afrique: entre informel et rationnel, l'exemple de Nouakchott (Mauritanie) [Urban Land in Africa between the Informal and the Rational: The Case of Nouakchott (Mauritania)]. Annales de Géographie 647: 69-91.

Cissokho, S. 2017. Petits échanges entre amis. Remarques sur l'ambivalence des rapports routiniers entre fonctionnaires et usagers au Sénégal [Little exchanges between friends. Remarks on the ambivalence of routine relationships between officials and service users in Senegal]. Revue française de science politique 67(4): 631-651.

Damiba, L. 2008. Les “entreprises” anti-corruption au Burkina Faso. Trajectoires, représentations et conflits [Anti-corruption "companies" in Burkina Faso. Trajectories, representations and conflicts]. Master en études du développement, Université de Genève.

de Maria, B. 2008) Neo-colonialism through measurement: a critique of the corruption perception index. Critical Perspectives on International Business 4(2-3): 184-202.

Debos, M. 2013. La guerre des préfets. Répression, clientélisme et illégalismes d'État dans l'entre-guerres tchadien [The Prefects' War Repression, Clientelism, and Illegal State Practices during the Interwar Period in Chad]. Politix 4(104): 47-65.

Dieng, M. 2015. La contribution des jeunes à l'alternance politique au Sénégal : Le rôle de Bul faale et de Y'en a marre [The contribution of young people to political alternation in Senegal: the Role of Bul faale and Y'en a marre]. African Sociological Review / Revue Africaine de Sociologie 19(2): 75-95.

Dieye, Ch. T. 2008. Les trajectoires de la corruption bureaucratique au Sénégal. Le cas des douanes [Trajectories of bureaucratic corruption in Senegal. The case of customs]. Thèse de doctorat en Etudes du développement, Institut des Hautes Etudes Internationales et du Développement. 
Diouf, M. 1992. Fresques murales et écriture de l'histoire. Le Set/Setal à Dakar [Mural frescoes and writing of history. The Set/Setal in Dakar]. Politique Africaine 46: 41-54.

Djallil, L. Dr. 2013. Al Qaida au Maghreb Islamique et le trafic de drogue au Sahel [Al Qaida in the Islamic Maghreb and drug trafficking in the Sahel]. Maghreb - Machrek 2(216): 111-128.

Fatton, R. 1986. Clientelism and patronage in Senegal. African Studies Review 29(4): 61-78.

Fay, C. 1995. La démocratie au Mali, ou le pouvoir en pâture [Democracy in Mali, or grazing power]. Cahiers d'Etudes Africaines XXXV-1(137): 19-53.

Foley, E. E. 2010. Your Pocket is What Cures You: The Politics of Health in Senegal. New Brunswick, NJ: Rutgers University Press.

Fomba, M. 2014. Les magistrats de terrain au Mali. Entre sollicitations et stratégies institutionnelles d'évitement [Field magistrates in Mali. Between solicitations and institutional avoidance strategies]. Afrique Contemporaine 250: 84-85.

Göpfert, M. 2016a. Repairing the law: The search for justice in the Nigerien gendarmerie. Theoretical Criminology 20(4): 446-461.

Göpfert, M. 2016b. Surveillance in Niger: Gendarmes and the Problem of "Seeing Things". African Studies Review 59(2): 39-57.

Grégoire, E. 2000. Les chasses du prince Bandar [Prince Bandar's hunts]. Autrepart 16: 87-97.

Gueye, M. 1997. Justice indigène et assimilation [Indigenous justice and assimilation]. AOF : réalités et héritages. Sociétés ouest africaines et ordre colonial, 1895-1960. C. Becker, S. Mbaye and I. Thioub. Dakar: Direction des Archives du Sénégal. 1: 153-169.

Hagberg, S., L. Kibora, S. Barry, S. Gnessi and A. Konkobo 2017. Transformations sociopolitiques burkinabè de 2014 à 2016. Perspectives anthropologiques des pratiques politiques et de la culture démocratique dans "un Burkina Faso nouveau” [Burkinabè socio-political transformations from 2014 to 2016. Anthropological perspectives of political practices and democratic culture in "a new Burkina Faso"]. Uppsala: Uppsala Universitet.

Hagberg, S., L. Kibora, F. Ouattara and A. Konkobo 2015. Au coeur de la révolution burkinabé [At the heart of the Burkinabè revolution]. Anthropologie \& développement 42: 199-224.

Hahonou, E. K. 2015. Juggling with the norms. Informal payment and everyday governance of healthcare facilities in Niger. Real Governance and Practical Norms in Sub-Saharan Africa. The Game of the Rules. T. De Herdt and J. P. Olivier de Sardan. London, New York: Routledge, 123-141.

Hahonou, E. K. 2016. Corruption, Insecurity and Border Control in Niger. DIIS Policy Brief.

Hamani, O. 2014a. Etude des dispositifs d'aide financière. Le cas du Niger [Study of financial aid mechanisms. The case of Niger]. Marseille: Prospective et Coopération.

Hamani, O. 2014b. "We make do and keep going”. Inventive Practices and Ordered Informality in the Functioning of the District Courts in Niamey and Zinder (Niger). States at Work. Dynamics of African Bureaucracies. T. Bierschenk and J. P. Olivier de Sardan. Leiden: Brill, 145-173.

Harman, S. A. 2014. Terror and Insurgency in the Sahara-Sahel Region: Corruption, Contraband, Jihad and the Mali War of 2012-2013. Farnham: Ashgate.

Harsch, E. 1993. Acccumulators and Democrats: Challenging State Corruption in Africa. The Journal of Modern African Studies 31(1): 31-48.

Jacob, J.-P. 2001. Introduction à la thématique des rapports entre corruption et sociétés anciennes. Les particularités du tiers inclus [Introduction to the theme of the relationship between corruption and ancient societies. The peculiarities of the included third party]. Morale et corruption dans les sociétés anciennes du Burkina (Bobo, Moaga, San et Winyé). Collectif. Ouagadougou: REN-LAC.

Jaffré, Y. and J.-P. Olivier de Sardan, éds. 2003. Une médecine inhospitalière. Les difficiles relations entre soignants et soignés dans cinq capitales d'Afrique de l'Ouest [Inhospitable medicine. Difficult relations between caregivers and patients in five West African capitals]. Paris: Karthala. 
Lange, M.-F. 1999. Insoumission civile et défaillance étatique: les contradictions du processus démocratique malien [Civil rebellion and state failure: the contradictions of the Malian democratic process.]. Autrepart 10: 117-34.

Lavigne Delville, Ph. and A. Abdelkader 2010. A cheval donné, on ne regarde pas les dents. Les mécanismes et les impacts de l'aide vus par des praticiens nigériens [On a given horse, we do not look at the teeth. The mechanisms and impacts of aid as seen by Nigerien practitioners]. LASDEL. Etudes et Travaux, 83: 113 p.

Legros, O. 2004. Les tendances du jeu politique à Yeumbeul (banlieue est de Dakar) depuis 1'“alternance" [Post-electoral political developments in Yeumbeul (eastern suburb of Dakar)]. Politique africaine 96(4): 59-77.

Magrin, G. 2010. Rentes, territoire et développement. Que tout change pour que rien ne change? [Rents, territory and development. Let everything changes so that nothing changes?] Bulletin de l'Association de géographes français 87(1): 56-68.

Masquelier, A. 2001. Behind the dispensary's prosperous facade: Imagining the state in rural Niger. Public Culture 13(2): 267-291.

Mathieu, M. 2000. Projets de développement et corruption. Prédispositions et effets d'entraînement [Development projects and corruption. Predispositions and training effects]. Monnayer les pouvoirs. Espaces, mécanismes et représentations de la corruption. G. Blundo. Genève, Paris: IUED, PUF: 123-155.

Mathieu, M. 2007a. La lutte contre la corruption au Bénin, au Niger et au Sénégal [The fight against corruption in Benin, Niger and Senegal]. Etat et corruption en Afrique. Une anthropologie comparative des relations entre fonctionnaires et usagers (Bénin, Niger, Sénégal). G. Blundo and J. P. Olivier de Sardan. Paris: APAD-Karthala, 317-346.

Mathieu, M. 2007b. "Une république autonome”. La corruption au quotidien dans un programme de coopération au développement au Sénégal [“An autonomous republic”. Daily corruption in a development cooperation program in Senegal]. Etat et corruption en Afrique. Une anthropologie comparative des relations entre fonctionnaires et usagers (Bénin, Niger, Sénégal). G. Blundo and J. P. Olivier de Sardan. Paris: APAD-Karthala: 285-315.

Nugent, P. 2010. States and Social Contracts in Africa. New Left Review 63: 35-68.

Olivier de Sardan, J. P. 1984. Les sociétés songhay-zarma (chefs, guerriers, esclaves, paysans...) [Songhay-Zarma societies (chiefs, warriors, slaves, peasants ...)]. Paris: Karthala.

Olivier de Sardan, J. P. 1999. A moral economy of corruption in Africa. Journal of Modern African Studies 37 : 25-52.

Olivier de Sardan, J. P. 2004. Etat, bureaucratie et gouvernance en Afrique de l'Ouest francophone. Un diagnostic empirique, une perspective historique [State, bureaucracy, and governance in French-speaking West Africa. An empirical diagnostic: A historical perspective]. Politique Africaine 96: 139-162.

Olivier de Sardan, J. P., Ed. 2015. Elections au village. Une ethnographie de la culture électorale au Niger [Elections in the village. An ethnography of electoral culture in Niger]. Paris: Karthala.

Olivier de Sardan, J. P. 2017. Rivalries of proximity beyond the household in Niger: political elites and the baabizey pattern. Africa 87(1): 120-136.

Olivier de Sardan, J.-P. and M. Tidjani Alou, Eds. 2009. Les pouvoirs locaux au Niger. Tome 1: A la veille de la decentralization [Local authorities in Niger. Vol. 1 On the eve of decentralization]. Paris: CodesriaKarthala.

Ould Ahmed Salem, Z. 2001. "Tcheb-tchib” et compagnie. Lexique de la survie et figures de la réussite en Mauritanie ["Tcheb-tchib" and company. Glossary of survival and figures of success in Mauritania]. Politique Africaine 82: 78-100.

Ould Cheikh, A. W. 2003. La science au(x) miroir(s) du prince. Savoir et pouvoir dans l'espace arabo-musulman d'hier et d'aujourd'hui [Science in the mirror (s) of the prince. Knowledge and power in the Arab-Muslim space yesterday and today]. Revue des mondes musulmans et de la Méditerranée 101-102: 129-155.

Ridde, V. 2012. Réflexions sur les per diem dans les projets de développement en Afrique [Reflections on per diems in development projects in Africa]. Bulletin de l'APAD 34-36. 
Samuel, B. 2011. Calcul macroéconomique et modes de gouvernement : les cas de la Mauritanie et du Burkina Faso [Macroeconomic calculation and modes of government: the cases of Mauritania and Burkina Faso]. Politique Africaine 124: 101-126.

Sarassoro, H. 1990. La corruption et l'enrichissement sans cause en Afrique aujourd'hui [Corruption and unjust enrichment in Africa today]. Afrique Contemporaine 4(156): 195-206.

Smith, D. J. 2003. Patronage, per diems and the "workshop mentality": The practice of family planning programs in southeastern Nigeria. World Development 31(4): 703-715.

Smith, M. G. 1964. Historical and Cultural Conditions of Political Corruption among the Hausa. Comparative Studies in Society and History 6(2): 164-194.

Sounaye, A. 2016. Islam et modernité. Contribution à l'analyse de la ré-islamisation au Niger [Islam and modernity. Contribution to the analysis of re-Islamization in Niger]. Paris: L'Harmattan.

Tidjani Alou, M. 2001. La corruption quotidienne au Niger [Daily Corruption in Niger]. La Corruption au quotidien en Afrique de l'Ouest. Approche socio-anthropologique comparative: Bénin, Niger et Sénégal. G. Blundo and J.-P. Olivier de Sardan. Marseille: EHESS, IUED, IRD, 109-171.

Tidjani Alou, M. 2006. Corruption in the legal system. Everyday corruption and the State. Citizens and public officials in Africa. G. Blundo and J. P. Olivier de Sardan. London: Zed Books. 137-176.

Touquet, C. 2010. Quand la colonisation perpétua les rapports de pouvoir propres aux sociétés de cour [When Colonization Perpetuates the Power Relationships Specific to Court Societies]. L'Homme et la société 1(175): $39-56$.

Vari-Lavoisier, I. 2014. The Circulation of Monies and Ideas between Paris, Dakar, and New York: The Impact of Remittances on Corruption. Center for Migration and Development Working Paper Series: 50.

Verschave, F.-X. 1998. La Françafrique. Le plus long scandale de la République [Françafrique. The Republic's longest scandal]. Paris: Stock.

Verschave, F.-X. 2000. Noir silence. Qui arrêtera la Françafrique [Black silence. Who will stop Françafrique]? Paris: Les Arènes.

Winters, M. S. and J. A. Gould 2011. Betting on oil: The World Bank's Attempt to Promote Accountability in Chad. Global Governance 17(2): 229-245. 